\title{
THE MULTIPLE ROLES OF HEANEY'S LANDSCAPES: A MIRROR OF LIFE AND ITS DILEMMA
}

\author{
David C. E. Tneh \\ Tunku Abdul Rahman University, Malaysia \\ tnehce@utar.edu.my \\ DOI: https://doi.org/10.24071/ijhs.2018.010202
}

received 25 November 2017; revised 2 Dec 2017; accepted 19 February 2018

\begin{abstract}
This paper discusses the timeless appeal of the poetry of Seamus Heaney, the poet laureate of Ireland and Nobel Prize winner for literature (1995). This paper traces the early developments of Heaney's poetry and highlights how the creative genre offers a dialogic platform (even in the 21st century) for national and political issues. Heaney's poetry transcends geographical boundaries with its evocative imagery and fluidity of time and space that is alluring, enigmatic, and striking. This paper will then discuss how multiple roles of Heaney's metaphorical landscapes from his five collections of poetry (from 1966 to 1979) namely Death of a Naturalist, Door into the Dark, Wintering Out, North, and Fieldwork are not merely poems about the nature, the environment, and Ireland but are instruments about his socio-economic/political views concerning idyllic Irish rural life, memories, nationalism, sectarian violence, colonial British rule, and his Catholic faith. The discussion of his selected poetry offers a deep intimate insight of Heaney's earlier poetry that mirrors Irish life and its struggles with nationhood.
\end{abstract}

Keywords: seamus heaney, poetry, nationalism, identity, politics

\section{Introduction}

Seamus Heaney was born on $13^{\text {th }}$ April 1939 in the townland of Mossbawn, County Derry, Northern Ireland (Morrison, 1982, p.13) The son of a Catholic farmer and cattle dealer, Heaney attended a local primary school in Anahorish and later he won scholarships to St. Columb's College, Derry (19511957) and from there he completed his tertiary education at Queen's University Belfast (1957-1961) achieving a first-class honours in English language and literature. He was active in a local dramatic society and published several poems in the university's undergraduate literary magazine. His later years in academia were spent teaching at St. Thomas's secondary school, Belfast, St. Joseph's college, Queen's University and later as a guest lecturer at University of California in 1971. His more popular works include Death of a Naturalist (1966), Door into the Dark (1969). Wintering Out (1972), North (1975), and Field Work (1979). Heaney is a Foreign Member of the American Academy of Arts and Letters and was Professor of Poetry at Oxford University (1989-1994). In three decades of writing poetry, he has won numerous literary awards, the most notable being the Nobel Prize in Literature award in 1995. 
Seamus Heaney, being an Irish writer from Northern Ireland, now still under British rule, distinguishes himself as the second greatest writer from Ireland after William Butler Yeats (1865-1939). Coming from turbulent Northern Ireland where the current political situation is still unresolved between the IRA and the British government, Heaney writes in a multiplicity of themes that are relevant to his beloved homeland and to his inner self. This paper will discuss his earlier works that cover multiple landscapes of the Irish countryside to its lifestyle, from rural to urban and the transforming and evolving scenery drifts along various concerns ranging from his childhood memories in County Derry farm to wider social and political aspects as well. What is equally imperative in this paper is how Heaney utilizes poetry as a quest to understand and discover a historical framework to analyse the current political turmoil and this paper will also demonstrate Heaney's use of metaphorical landscapes (such as the landscapes of nature and the human mind) as a bridge to understand the social and political issues that affect Ireland.

Being Ireland's most celebrated poet, Blake Morrison (1982) comments that one of Heaney's "ambivalence concerns his response to the recent history of Northern Ireland, the crisis of which has placed poets under the compulsion to respond" (p.15). In this, Heaney finds himself torn between what Elmer Andrews comments as "...the sectarian crossfire with fellow Catholics pressuring him to write political verse and liberal critics congratulating him on not taking sides” (Andrews, 1988, p.1). Heaney's earlier poetry is often mired with "a sense of deep loss and even moral guilt" ("This is not a Spade: The Poetry of Seamus Heaney," 2007). Being a nationalist, Heaney found it ironic to be using the language of the colonizers to highlight the deep seated issues that trouble the inner psyche of the Irish folk but being a public poet, Heaney realizes that the role of language should have its importance to serve the community. Perhaps this is what Heaney meant when he says in his prose work, Preoccupations. "Art has a religious, a binding force, for the artist. Language is the poet's faith of his fathers and in order to go his own way and to do his proper work in an agnostic time, he has to bring that faith to the point of arrogance and triumphism” (Heaney, 1980).

\section{Method}

As a literary paper, the qualitative approach is utilized with textual analysis and close reading is the method employed in understanding the poetry of Seamus Heaney. This paper discusses selected poetry from Seamus Heaney's earlier collection such as Death of a Naturalist, Door into the Dark, Wintering Out, North, and Fieldwork. Comparison is made between the poems and a thematic approach is undertaken to analyse the poems to the overarching concerns of the paper. This approach is common in literary analysis as the text(s) is/are the central focus of the discussion. For a more comprehensive understanding, comparisons with other literary works will be done to widen the analytical scope of the analysis.

\section{Findings and Discussion}

Heaney's first two volumes of collected poetry Death of a Naturalist and Door into the Dark offer us a glimpse of the landscapes of Irish rural life. The landscapes in Heaney's poetry portray an outlet for his imaginative mind to 
explore the boundaries inaccessible by the explorations of the human self. It is through the landscapes of the mind that he conjures up images of the past that speaks well of historical occasions as well as its associations with the future. In Heaney's first collection "Death of a Naturalist" the landscape of nature also returns to his childhood experience. The poem begins with a scenic description of a flax-dam being populated with new life in the lines:

All year the flax-dam festered in the heart

Of the townland; green and heavy-headed

Flax had rotted there, weighted down by huge sods.

Daily it sweltered in the punishing sun.

Bubbles gargled delicately, bluebottles

Wove a strong gauze of sound around the smell.

There were dragonflies, spotted butterflies,

But best of all was the warm stick slobber

Of frogspawn that grew like clotted water

In the shade of the banks.

(Heaney, 1988, p.5)

The force of nature unleashing its fury on the persona encapsulates Heaney's portrayal of the natural landscapes from its stage of innocence to its wrathful burst of energy and violence.

Then one hot day when the fields were rank

With cowdung in the grass the angry frogs

Invaded the flax-dam; I ducked through hedges

To a coarse croaking that I had not heard

Before. The air was thick with bass chorus.

Right down the dam gross-bellied frogs were cocked

On sods; their loose necks pulsed like sails. Some hopped:

The slap and plop were obscene threats. Some sat

Poised like mud grenades, their blunt heads farting.

This sudden physical encroachment by the frogs shows the demystifying of nature as a benign landscape that many thought it to be. This wild play of the imagination demonstrates Heaney's tapping into the vivid universe of his childhood world of experience, creating the rituals of rural life that project and gratifies our tactile senses to the sounds of nature. By the projection of past images too, is Heaney's way for an answer for the future, Elmer Andrews comments "Heaney's preoccupation with his own childhood is indicative of a pietism which looks for an inviolate origin, a pure source. In childhood, the poet may recognize the secret moments of his deepest self. The response of the child are the primary movements of his humanity, and finds and enlarges his freedom" (Andrews, 1988, p.8).

In the poem "Follower", Heaney (1980) describes his father ploughing the fields, while he is the follower that cannot catch up with the energy sapping activity so much so that he "stumbled in his hob-nailed wake/ Fell sometimes on the polished sod;/ Sometimes he rode me on his back/ Dipping and rising to his plod” (p.18). Thus in this poem, the rural farming landscape provides Heaney 
with a scenario of his doubts and "self-consciousness about the relationship between 'roots and reading', the live and the learned" (Andrews, 1988, p.8). It is here too that Heaney searches for answers to his roots; the ploughing of the land symbolizes his deep search for his identity, a truly difficult task when Heaney was young but eventually he bridges this with the symbiosis between the landscape and the poet, by means of his poetry that reconciles the tension. Heaney does this by studying the works of Patrick Kavanagh whose dilemma seems to parallel to Heaney's, especially the conflict between the poet and life on the land longing for "the city of Kings/ Where art, music and letters were the real things" (Heaney, 1980, p.137). Heaney thus learns from Kavangh the "management of ironic points-of -vantage on his material promoted the expression of more subtle, complex feelings about the relationship between the poet and place” (Andrews, 1988, p.9).

Thus in "Death of a Naturalist", Heaney (1988) writes of the simplicity of Irish rural life that soon is to be linked with larger issues at hand. From the spectrum of colours in "Blackberry-Picking” (p.7):

Late August, given heavy rain and sun

For a full week, the blackberries would ripen.

At first, just one, a glossy purple clot

Among others, red, green, hard as knot.

To the vivid and descriptive "Churning Day” (p.8)

Where finally gold flecks

began to dance. They poured hot water then,

sterilized a birchwood bowl

and little corrugated butter spades.

Their short stroke quickened, suddenly

a yellow curd was weighting the churned-up white,

heavy and rich, coagulated sunlight...”

Heaney's poetry reaffirms the old way of Irish life against a modern world of changing values and the fast - paced rhythm of it that threatens the old way of living. Heaney combines the landscapes of nature and the molding of it in his imagination to eventually enter the embracing arms of solitude, peace and tranquility or in the words of Elmer Andrews, "desire to enter into communication with mystery-is expressive of his notion of art as divination and revelation" (Andrews, 1988, p.27).

Thus, the landscape panorama that Heaney frames in his first collection of poetry gives us a flawless image of life fully equipped with its beauty, serenity as well as its rustic charm. But there is more to this than just picturesque poetry. One must consume the poetry of Heaney with its entire dynamics as well. Andrews comments that

It is only when we attend to the details of Heaney's recreation of the rural world that we find implications of a larger social and moral order, an inheritance for which the poet feels incapacitated by his own sensibility. There is a notion of discontinuity, a feeling of loss, a sense of guilt, an apprehension of violence as 
well as of beauty, lying deep in things. These feelings constitute in germinal form the basic postures and dynamics underlying Heaney's entire poetic oeuvre (Andrews, 1988, p.23).

In Heaney's second collection, "Door into the Dark”; we are thrusted into the imaginative stores of his mind in near darkness. The title itself comes from the poem entitled "The Forge" which describes metaphorically a place where ideas of the imaginative creation is conceived and produced by force by the blacksmith. The darkness is a place of reverence for Heaney because it's from the darkness itself comes forth the flames of the forge that bends and twists the shapeless ideas of the mind into the sharpest creation. The blacksmith's tool is the anvil that is used to create the fruits of his labors. Heaney describes it powerfully in the lines,

The anvil must be somewhere in the centre

Horned as a unicorn, at one end square,

Set there immoveable: an altar

Where he expends himself in shape and music

(Heaney, 1988, p.20)

Similarly in "The Thatcher", Heaney (1988) associates it with another power of creation, that is the weaving and transformation of nature's raw materials into creations of a bygone era, this speaks well of his intention to bring forth into light the traditional craftsmanship of an ancient era. The "Thatcher" is described as having “a Midas touch” (p.21).

Couchant for days on sods above the rafters

He shaved and flushed the butts, stitching all together

Into a sloped honey comb, stubble pitch,

And left them gaping at his Midas touch.

This power of creation is similar to that of the blacksmith and Heaney unravels this too, in the creative force of the ancient landscapes of Ireland known for its myths and lore. In the poem "Bogland" (Heaney, 1988. p.41) 19 this damp, murky and unscenic landscape fascinates Heaney, "Heaney's poetic realm he identifies it in 'Bogland', is not the wide-ranging expansive prairie: it is vertical rather than horizontal, lying in the depths of personal and communal experience" (Andrews, 1988, p.34).

Heaney perceives the bog land in the poem as a representation and expression of the Irish culture. It is also a landscape that Heaney tries to expound further upon the roots of Ireland by unraveling and shedding the layers upon layers of mystery that surrounds his poem. This is well expressed in the lines:

Melting and opening underfoot,

Missing its last defination

By millions of years.

They never dig coal here,

Only the waterlogged trunks

Of great firs, soft as pulp. 
Our pioneers keep striking

Inwards and downwards,

Every layer they strip

Seems camped on before.

The bogholes might be Atlantic seepage

The wet centre is bottomless.

(Heaney, 1988, p.41).

The bog pits being a part of the landscape of Ireland for so long never could reveal much of the country's origin. Even though relics of the old and fossils from a pre-Christian era were uncovered from the bogs, an excavation of the entire area never could reveal much of Ireland. Its deep centre acts as a black hole that is timeless and never ending. Elmer Andrews comments that:

There is, in Heaney's poetry, sense of Ireland as an old dark, the secret depths, the cultural past, the pioneer in search of origins runs the risk of getting lost in mists and swamps...beyond all possibility of renewal, lies the formless, primeval level of history and consciousness-the mysterious source of life (Andrews, 1988, p.35).

Heaney often writes of the past so that he can write on the future, therefore the poet traces his love of poetry back to his childhood days. Similarly he does this for his love for nature too. From the first two collections, Heaney gradually extends the explorations of his self to the explorations of the landscape and its relation to the communal past. The landscape is sacramental for Heaney as he uses it once again in his third collection of poems, "Wintering_Out" (1972). Morrison says, "What 'Wintering Out' does is to explore the deeper structures of present hostilities, the way in which the divisions of the Protestant and Catholic communities are embedded in the language and topography...he continues to draw from a rich store of personal memory, but also opens up much wider perspectives of history" (Morrison, 1982, p.39) In Heaney's selected prose, "Preoccupations", he writes of the physical land that assumes various roles including implicit social and historical dimensions embedded in it. In relation to this, "Wintering Out" portrays Heaney's concerns of the political crisis in Ireland in the 1970's as well as Heaney's obsession with the peat bog that revels the past and the future events of Ireland all together.

Heaney's poetry in "Wintering Out" gives us the impression that he does not leave the charm of the Irish world but instead moves deeper into the heart of his Irish roots by naming certain places of his youth. Names like "Derrygarve", "Anahorish", combines the roots of the natural Gaelic languages with the native tradition and topography of the Irish countryside to portray the sweeping river, an image of the Anglo-Irish dialect that sweeps across the "shiny grass and darkened cobbles" (Heaney, 1988, p.47) The poem "Broagh" (which means riverbank) is another example of what John Wilson Foster says as "another small hymn to a Londonderry place-name which also rehearses in sound the landscape it labels" (Foster, 1995, p.34) The rain in the poem:

ended almost

suddenly, like that last 
gh the strangers found

difficult to manage.

(Heaney, 1988, p.55)

The Irish place-names, pronunciations and its identity with the land are Heaney's way of reviving the importance of the Anglo-Irish dialect from being swamped by the Anglo-Saxon language and tradition. Not only does Heaney searches for the 'Word', the poem “Toome” gives light into Heaney's search for the core of his homeland.

My mouth hold round the soft blastings,

Toome, toome, as under the dislodged

slab of the tongue

I push into a souterrain prospecting what new in a hundred centuries

loam, flints, musket-balls, fragmented ware, torcs and fish-bones till I am sleeved in

alluvial mud that shelves suddenly under bogwater and tributaries, and elvers tail my hair.

(Heaney, 1988, p.54)

Heaney imagines the way the word "Toome" is pronounced, by means of moving ones lips forward and lifting the tongue. By means of this "soft blastings", he finds "loam, flints, musket-balls, fragmented ware, torcs and fish-bones..." from the "souterrain". Morrison (1982) describes the word as "underground chambers scattered in there thousands about Ireland, often associated with ancient burial mounds and occasionally used to store away smuggled goods and arms" (p.44). Heaney's description of the "alluvial mud" describes this successful act of reaching his "primeval source of his selfhood and race... He has done so not by leaving his native ground but by looking into it more deeply; he chooses excavation rather than exile" (Morrison, 1982, p.44).

"The Tollund Man" meanwhile is another of Heaney's bog poems that well illustrates his passion for the Irish political martyrdom as he connects the images of bodies in Danish bogs dating to the Iron Age to the real political situation in Ireland. "The dead bodies are sacrificial victims to the Mother Goddess, Nerthus, the goddess of the ground, who requires new bridegroom each winter to bed with her in her sacred place in the bog, to ensure renewal and spring fertility" (Andrews, 1988, p.64). 
Heaney's portrayal of the "Tollund Man", found in the depths of the bog is an image of renewal and hope. The sacrifices committed in the past are similar to the sacrifices done by his countrymen against the rule of the British. Therefore, it provides an understanding to the violence that continues in present day Ireland. The modern day violence of Ireland is a continuum from the past; the blood shed is for the benefit of Mother Ireland. Heaney also treats the poem as a kind of devotion,

I could risk blasphemy, Consecrate the cauldron bog Our holy ground and pray

Him to make germinate

The scattered, ambushed

Flesh of laborers, stockinged corpses

Laid out in the farmyards.

(Heaney, 1988, p.62-63)

Heaney perceives the man to be a "possible intercessor to which the poet would pray to redeem his slaughtered countrymen" (Andrews, 1988, p.64) Heaney sees the motivation that drove the sacrifices to be committed in the past to be similar to the Irish cause and their fight for independence. The "Tollund Man" is an ancestor to the modern day Irish political martyr and Heaney pictures the persona going to the Aarhus museum where the body is kept, to offer up to his prayers perhaps for a revelation or an answer to Ireland's political crisis.

Heaney's next collection "North" is considered as one of his darkest collections of poetry. While in "Wintering Out", Heaney tries to find a metaphor for his beloved Ireland, "North" is a detailed development of "setting ancient situations, perceived with freshness and immediacy and with a sensitivity to their disturbing and awe-inspiring mystery, against contemporary situations" (Andrews, 1988, p.84). While Heaney's other collection offer some form of hope and sustenance, "North" is a collection that speaks well of the darkest moods that prevail in Heaney's mind. Nevertheless, Heaney took a great leap of faith in his fourth collection, offering us no longer rustic and peaceful descriptive poems but his adamant and personal views that critics had argued, long overdue. Robert F. Garratt (1995) speaks of the "North" collection as framing "contemporary events within a larger historical narrative of ancient Celtic and Norse lore, metaphorically connecting the sectarian killings in Northern Ireland to the ritualized human sacrifice of pre-Christian Jutland. Here was the book that reviews felt were long overdue: an Irish writer confronting and interpreting the social and political issues of his day" (p.22).

This fourth collection is vital to the development and complexities of his other collections. There is a growth of the landscape and the mind. Heaney's references to the Iron Age society, Viking myths and legends, the rituals of the Catholic and Celtic including other ancient saga's as well, provides him with sources for his poetic debate without being accused of "partisanship". Therefore by doing so, Heaney is careful that should his poetry encompass politics, he is careful that it should not serve them. He writes to clarify his expression, his 
feelings and to give light to his search but definitely not to instil hatred in others. His preoccupations with the bogland are still obvious in "North" and this can be seen in the lines of “The Graubelle Man”.

hung in the scales

with beauty and atrocity:

with the Dying Gaul

too strictly compassed

on his shield,

with the actual weight

of each hooded victim,

slashed and dumped.

(Heaney, 1988, p.111)

The bog "transforms and preserves what it contains", (Shapiro, 1995, p.22) which is naturally true as in many archeological findings, near perfect bodies or artefacts that preserves the memories of the past, it even projects the violence of ancient killings long before the existence of a country named Ireland.

In the poem "Kinship", the violence of the past is mingled with sexual overtones as the bog is seen to be a place of dark mystery, exuviating an almost sexual kind of love. The bog is described as an "Insatiable bride/ Sword swallower, casket, midden,/ floe of history" (Heaney, 1988, p.116) Heaney now ventures in and out of his bog stronghold with the images of human sexuality and violence mingles together. The poem "Punishment" meanwhile sees the poet identifying with an ancient body of a female found in a bog. Obviously murdered, his sorrow turns to guilt in the following lines,

I who have stood dumb

when your betraying sisters,

cauled in tar

wept by the railings,

who would connive

in civilized outrage

yet understnd the exact

and tribal, intimate revenge.

(Heaney, 1988, p. 112)

The person then is dumbstruck as he watches her "betraying sisters" being shaved, tarred and tied to the railings in Belfast by the IRA s a punishment for dating British soldiers. He does nothing but finds himself torn between the feelings of approval and outrage. Stallworthy (1995) comments "his indictment is directed less against the betraying sisters than against the onlooker-himself-who would connive with those who inflict this punishment, whilst admitting to contradictory feeling of 'civilized' outrage and 'tribal' satisfaction" (p.181). However we simply must not judge Heaney as a brute that agrees with this kind of political violence because his expression is a poetic response or as Bernard O' Donoghue (1994) puts it “...the writer who has always declared the wish to 
represent the writing self as $\mathrm{n}$ example of the experiencing observer. So the judgment in he poem is not a moral or political one; it is an artistic one” (p.74).

In "Funeral Rites", Heaney portrays a Catholic burial and links it to the burial of Gunnar, a Viking hero and shows a "sadly repetitious and minimal ceremonies occasioned by 'each neighborly murder' in the Northern Ireland of the mid-1970's” (Hildebidle, 1995, p. 40). The poem is his method of linking the present with the past, of Viking heroism and present day Ireland. The death of the Viking is seen to be a beautiful moment.

Men said that he was chanting

verses about honour

and that four lights burned

in corners of the chamber:

which opened then, as he turned

with joyful face

to look at the moon

(Heaney, 1988, p.95).

What lies beneath this serenity is in fact the act of murder. Though the poem is edifying, Heaney is not too optimistic about the hopes of amity. "North" remains Heaney's response to the demands that public poet should have moral and social obligations as well in his writing. He has bowed to the pressures to write about the 'Troubles' and he has finally delivered.

Heaney's next collection entitled "Field Work"(1979) is written when he spent 4 years in the Republic in an area called Glanmore. His work represents a scaling down of his vision, no longer is he writing about the unlimited boundaries of the North, instead "Field Work" is concentrated on a smaller scope, the field, rather than the expansive landscapes of the mind and soul. His work is focused upon the community and its members. This collection mourns the death of his friends and contains six elegies though he has moved south, the Ulster sentiments in him is predominantly strong. Heaney has brought with him south his poetic voice and new meaning in his preoccupations and style.

The first poem "Oysters" opens with a feast as the poet and his friends are dining on oysters by the seaside. The oyster suddenly brings about some political and historical conscience in the poet.

Over the Alps, packed deep in hay and snow,

The Romans hauled their oysters south to Rome:

I saw damp panniers disgorge

The frond-lipped, brine-stung

Glut of privilege

(Heaney, 1988, p.139).

The poet is taken aback for a while and for once thinks of himself like the plundering Romans who once "split", violated", “ripped and shucked and scattered" the precious shellfish a long time ago. To proceed would be an act of historical plunder all over again but then he continues to gorge himself deliberately saying "And was angry that my trust could not repose/ In the poetry 
of freedom/ Leaning in from sea”. The poet decides that his fortitude shall not be dogged by historical events anymore instead he shall now rely on his poetic imagination. No longer will his "own sexual and political anxieties keep him from resting in the material happiness of the day;"(Vendler, 1995, p. 48) but instead he relies on the searching's of his mind.

“At the Water's Edge" describes a scene at Newry in 1972; sometime after British paratroopers shot 13 civil right marchers that henceforth became known as Bloody Sunday. The place is described as a spiritual waste land. The holy place was deserted, "Carved monastic heads/ Were crumbling like bread on water", even the pagan statues are falling apart such as "On Boa the god-eyed" and the basin that held holy water once now contains rainwater. The poet therefore looks up at the sky, hoping for a sign from God but what is prominent is "the thick rotations / Of an army helicopter patrolling” (Heaney, 1988, p.142). The poet longs for spiritual sustenance, hoping for an outlet for his expression but then what comes forth is political sustenance from the incidents of that fateful Bloody Sunday.

In "Casualty", Heaney writes of an acquaintance that was killed by a bomb blast when he defied the curfew on the neighborhood imposed by the IRA. Heaney uses this poem then to explore his relationships with "the tribe" that finally ends with the following lines.

As you find a rhythm

Working you, slow mile by mile,

Into your proper haunt

Somewhere, well out, beyond...

Dawn- sniffing revenant

Plodder through midnight rain,

Question me again

(Heaney, 1988, p.150).

Heaney feels that his poetic vocation had occasionally alienated him from his people and his friend who was killed appears again and again as a ghost that questions him repeatedly his ways defying "the tribe". Heaney does not answer but then what appears is "the primary of mysterious, elemental forces, carrying him beyond the time---bound politics of the tribe” (Andrews, 1988, p.125).

\section{Conclusion}

Heaney thus uses his power of the language to transgress the constraints of "the tribe". He asserts his own independence in the end and celebrates it as a kind of "artistic activity" (Morrison, 1982, p.78). Heaney rejects some of the old values of the past and in "Field Work" reasserts himself in the quest for his own identity and meaning. In his journey for poetic development, he reaches a completion of that journey that began in 1966. His search for the answer in the Irish landscape is found in his poetry, a platform of political attitudes that mirror the desperateness of a situation that needs to be addressed.

Heaney's poems are for him the main medium of which he works his art; that is sowed his ingenuity and the belief of the struggle to protect his believes, 
and also "to speak out for injustice." ("Violence in Seamus Heaney’s Poetry," 2017). Poetry, according to Heaney should have its own "vindicating force" and an authority of its own. This is what Heaney (1986, p. 93) meant in his critical writing "The Government of the Tongue", that a poem has a biological right to exist and the poet is therefore "credited with a power to open unexpected communications between our nature and the nature of the reality we inhabit."

\section{References}

Andrews, E. (1988). The poetry of seamus heaney. London: Macmillian Press.

Buttel, R. (1975). Seamus heaney. London: Associated Uni Press.

Foster, J.W. (1995). The poetry of seamus heaney (on wintering out). Critical Essays on Seamus Heaney. New York: G.K. Hall \& Co.

Garratt, R.F. (Ed.). (1995). Critical essays on seamus heaney. New York: G.K. Hall \& Co.

Heaney, S. (1980). Preoccupations. London: Faber \& Faber.

Heaney, S. (1980). Selected Poems. London: Faber\& Faber.

Heaney, S. (1988). The government of the tongue: The 1986 T.S. Eliot memorial lectures and other critical writings. London: Faber \& Faber.

Heaney, S. (1998). Opened ground: Selected poems 1966-1996. New York: Strauss.

Hildebidle, J. (1995). Decade of Seamus Heaney's Poetry. Critical essays on Seamus Heaney. New York: G.K. Hall \& Co.

Larsmo, O. (2007). This is not a spade: The poetry of Seamus Heaney. Retrieved from https://www.theguardian.com/books/2013/sep/06/seamus-heaneypoet-blake-morrison

Lavan, R. (2014). Seamus heaney's places. Retrieved from http://www.oxonianreview.org/wp/seamus-heaneys-place/

Mambol, N. (2017). Violence in seamus heaney's poetry. Retrieved from https:/literariness.org/2017/11/20/violence-in-seamus-heaneys-poetry/

Morrison, B. (1982). Seamus Heaney (Bradbury, M., \& Bigsby, C.,Eds.).London: Methuen.

O’Donoghue, B. (1994). Seamus heaney and the language of poetry. New York: Harvester Wheatsheaf.

Shapiro, A. (1995). Crossed pieties (on the early poetry). Critical Eessays on Seamus Heaney. New Yok: G.K. Hall \& Co.

Stallworthy, J. (1995). The poet as archaeologist. Critical Essays on Seamus Heaney. New York: G.K. Hall \& Co.

Vendler, H. (1995). The breaking of style: Hopkins, heaney and graham. London: Harvard Uni Press. 